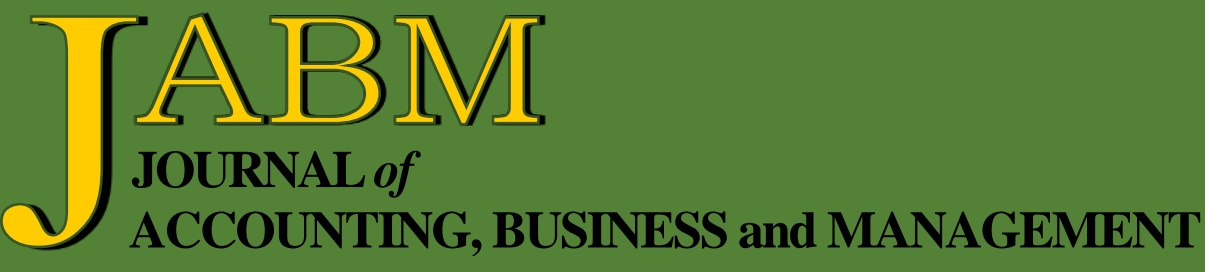

Towards Understanding the Effects of Web 2.0 at the Project Level Knowledge Management on Projects' Success

Anupam Kumar Nath

Sticky Costs and Expenses are not Alike: Mexican Reality

Luis Felipe Llanos Reynoso, César Vela-Beltrán-del-Río, and

José Luis Martínez-Berrones

Business Sustainability Through Environmental and Operational Management in Five Star Hotels in Amman, Jordan

Haitham Abdelrazaq, Taghreed Aljaffal, Pheroza Daruwalla, and

Karina Wardle

Impacts of Asset Utilization, Market Competition and Market

Distance on Stock Returns

Jeanne-Claire Patin, Matiur Rahman, and Muhammad Mustafa

Accounting Conservatism, Information Asymmetry and

Cash Holdings

Walid Shehata and Ahmed Rashed

An Investigation of the Relationship between Corporate Social Responsibility and Corporate Financial Performance in Egypt: The Mediating Role of Information Asymmetry

Nancy Mohamed and Ahmed Rashed

The Impact of Regulatory Capital and Bank Characteristics on the Relationship between Bank Competition and Risk Taking in the Banking System

Eman Abdel-Wanis

Firm Size, Firm Age, and Firm Profitability: Evidence from China Md. Jahidur Rahman and Liu Yilun 
Journal of Accounting, Business and Management vol. 28 no. 1 (2021) 31-51

\title{
Business Sustainability Through Environmental and Operational Management in Five Star Hotels in Amman, Jordan
}

\author{
Haitham Abdelrazaq* \\ Taghreed Aljaffalt \\ Pheroza Daruwalla \\ Karina Wardle§
}

\begin{abstract}
This paper aims to investigate sustainable environmental performance in five-star hotels in Amman, Jordan. The primary objective of the study is to determine the impact of business and operational practices of five-star hotels in Amman. The research focuses on five operational departments, including maintenance and security (MS), food and beverage $(\mathrm{F} \& \mathrm{~B})$, kitchens $(\mathrm{K})$, purchasing $(\mathrm{P})$, and housekeeping $(\mathrm{H})$. This study adopted a qualitative method, using semi-structured interviews as the primary source for collecting extensive data. Moreover, the study employed quantitative instruments in data collection using a survey instrument and non-participatory observation as triangulation to the qualitative method. The study involved respondents from 13 fivestar hotels in Amman, Jordan. This paper examines the impact of operational business practices on environmental sustainability in five-star hotel properties in Amman. It suggests ways in which sustainable practices can contribute positively towards allowing hotels to achieve better performance towards the environment. The findings showed that all five-star hotels applied different sustainable practices in their daily operations to achieve sustainable environmental performance. Most of the respondents from the five operational departments acknowledged that suitable use of water and energy savings were the preferred choices that aided sustainability practices in the hotel properties
\end{abstract}

Keywords: environmental sustainability, five-star hotels, and Jordan.

\section{INTRODUCTION}

Tourism and its various activities are closely related to the natural environment. Natural environmental attractions are classified as one tourism's most important resources and magnet, especially when accompanied by ecologically sustainable maintenance and tourist management. The development of environmental resources contributes to and aids the growth and prosperity of tourism, and therefore tourism and the environment are separate sides of the same coin. Contemporary issues of environmental protection against the risks of pollution and sustainable use of resources, whether natural, human or technological have become significant to hospitality businesses and the local community's in which they operate. Internationally and locally, the hotel industry recognises the importance of balancing environmental and societal needs. Environmentally friendly practices often referred to as "green" applications have

\footnotetext{
* School of Business, Western Sydney University. Phone: +614 2 4650566. E-mail: H.abdelrazaq @ city.westernsydney.edu.au.

† School of Business, Western Sydney University. E-mail: t.aljaffal@westernsydney.edu.au.

‡ School of Business, Western Sydney University. E-mail: P.Daruwalla@westernsydney.edu.au.

$\S$ School of Business, Western Sydney University. E-mail : K.Wardle@westernsydney.edu.au.
} 
a positive return in terms of reducing costs, gaining a good reputation and ensuring attractiveness of the hotel to consumers. In the long term, the application of green practices can lead to a reduction in direct costs by carefully managing energy and water consumption, wastewater treatment and disposal of solid waste. Environmental conservation efforts, such as adequate hazardous waste management and water treatment, have the added benefit of providing a safer work environment and conserving surrounding areas (Wyngaard \& De Lange, 2013).

Environmentally friendly sustainable tourism facilities are growing as one of the most important trends in the global tourism field, and their activities are directed toward developing the surrounding environment and maintaining ideal business practices. Countries all over the world, including in the middle east are increasingly shifting to concepts of sustainability and 'greening' their hospitality and tourism practices. They are working hard to raise knowledge and awareness of efficient use of water and energy resources, waste recycling, constrained consumption and thoughtful changes to amenities and operational aspects in order to achieve green credentials and a positive economic return on the facility. The recognition that over-tourism contributes directly to environmental and societal environments is receiving increased attention in both academia and industry.

Tourism institutions, organisational groups and hotel owners have turned their attention to minimising environmental damage, being innovative and creating new opportunities for ancillary businesses and internal start-ups, including things like rooftop edible gardens, solar panel and hybrid power saving devices and retro fitting of low power lighting. Seetharaman et al. (2016, p. 45) highlight the importance measuring operational performance from a variety of perspectives including "accounting, financial and non-accounting and non-financial". They rationalise that the crux of any business is to perform satisfactorily on a number of metrics and in-service industry's like hospitality and tourism, intangibles are highly significant indicators of success or failure of a business. These include aspects like reputation, service experience, ambience, and operational commitments and displays of environmental sustainability aspects.

A referendum conducted by the European (travel weekly) magazine, explored the interests and desires of tourists related to environmental issues and sustainability finding that fifty percent of consumers are willing to pay additional amounts for their stay in a hotel with 'green' credentials. Some of the respondents expressed doubts about the initiatives launched by some hotels regarding their 'green' stances as being simply greenwashing (Manaktola \& Jauhari, 2007; Han et al., 2010; and Kang et al., 2012). These perceptual problems will continue to exist for the hospitality and tourism industry unless they are able to demonstrate and communicate these initiatives in authentic contexts.

The international business leaders forum (ABLF) encouraged the uptake of green credentialing in the hotel sector as well as in general tourism and travel venues and attractions. The establishment of the international tourism partnership (ATB) in 1992 was seen as further commitment to these efforts to formalise greening of the hospitality and tourism industry. Some of the initiatives emerging from the ATB included finding ways and means to deal with the environmental management of hotels. These initiatives encompassed issuing guides specifying design and building metrics to qualify as sustainable properties; and introducing rigorous inspections resulting in certifications allowing hotels to advertise themselves as green hotels. Other measures included undertaking the education of hotel guests about water conservation through reusing bath and bed linen instead of daily washing; internal modifications like water 
saving shower heads, sensor taps and lights; reduction of harsh chemicals in laundering and cleaning and not overloading electrical appliance sources in the rooms, public areas or operational spaces.

Organisations like "green globe" based on international standards for the application of sustainability in the travel and tourism field, operate under the global license in California, USA, representing more than 83 countries. Green globe is an associate member of the world tourism organization (UNWTO), and a member of the global sustainable tourism council (GSTC) and has considerable clout and brand power in the hospitality and tourism industry sector. This international recognition is a spur for countries in the middle east (ME) to ensure that their properties are not only meeting but also exceeding the world standards for sustainable enterprises.

Abu Dhabi, in the United Arab Emirates, began implementing the standards of green hotels in a pilot manner in 2010. They mandated that new four- and five-star hotels had to adhere to them and rolled them out to one hundred and twenty new facilities. The resultant 20\% reduction in waste and 10\% in electrical energy savings that would apply from adopting such measures, were cited as reasons for the roll out of these environmental measures. However, different countries have disparate economic conditions in the ME due to contrasting economic conditions. Jordan, is one such country where unlike its neighbours to the east and south, Jordan has a heavy reliance on phosphates, agricultural produce, foreign aid and tourism in the absence of oil production (Al-Hussein et al., 2015; Al-Shawagfih et al., 2015).

As early as 1995, Kirk noted that Jordan adopted a number of environmental sustainability measures and practices with a view to protecting the environment in addition to increasing the awareness of hotel and resort guests about environmental protection initiatives. The early recognition in Jordan of the need to preserve their heritage and tourism from over consumption was initiated based on historical and natural tourism attractions like Petra and the Dead Sea that tourists were keen to experience. The economic imperatives and earnings from tourism and the introduction of multinational companies into the Jordanian economy were a consideration that needed to be balanced with environmental sustainability. One such international hotel chain, Mövenpick resorts \& hotels, implemented a wide range of environmental policies to reduce water, energy and waste consumption. The Mövenpick resort \& spa, located at the dead sea, were recognised as being leaders in waste management. Movenpick properties located in Aqaba and Tala Bay actively adopted ecotourism initiatives like solar car travel around the resorts. The Mövenpick hotel, Petra and the Mövenpick hotel, nabati castle also reduced waste by installing modern water conservation devices in guest rooms and toilets. The focus on raising environmental awareness of both internal (employees) and external (guest) stakeholders was done with a view to still maintaining and increasing high service standards and an exceptional guest experience at the property. Anecdotal evidence emanating from global tourists reveal their interest and investment in the care of the environment thus preserving the amenity of the attraction and benefiting both tourists and locals.

The next section examines the literature on aspects of environmental management in the hospitality industry and Jordan specifically.

\section{THEORETICAL PERSPECTIVE}

\subsection{Literature Review}

The focus of this section is to explore findings in the existing literature on different aspects of achieving sustainable performance in the hotel industry in Jordan. 
There is a limited body of literature on environmental practices in the Jordanian hotel and tourism sectors and this was reviewed as well.

Like many places in the world Jordan considers tourism as a primary focus of its economic revenue. Ballantyne and Pickering (2013) noted that Tourism is often cited as the world's largest industry and continuing to expand at a rapid rate. Tourism is also a profitable economic endeavour which makes it an economically enticing industry and a form of development for many countries around the world. The hotel industry is considered as a significant division of the hospitality industry, and if not managed sustainably, it has the potential to be harmful to the social and natural environments within which it functions and operates. These 'truisms' about tourism, however, have been shaken in the light of the COVID-19 pandemic, and it's impacts world-wide. Questions being currently asked include whether environmental sustainability and climate change issues will take a backseat while countries both developed and developing attempt to regain economic equilibrium post COVID-19. The Hashemite Kingdom of Jordan will grapple with this issue too, but this is outside the scope of this paper as the data was collected well before the pandemic.

Tourism is one of Jordan's primary sources of foreign currency, attracting tourists from all around the world due to its political stability, religious tolerance, a higher quality of life, better healthcare and education compared with surrounding areas, exquisite cuisine, friendly and welcoming people, together with a reasonably liberal social and economic environment, as tourist brochures often point out. Geographically, Jordan is located in the Western Asia region and it has a surface area of approximately $90,000 \mathrm{~km} 2$. Most of Jordan's territory is classified as desert. Jordan is a very sunny country with average daily sunshine hours ranging from six to seven hours in winter and as much as twelve to thirteen hours in summer. However, limited resources such as oil, water, and other natural resources, contribute to the Jordanian economy being substantially less than that of comparable middle eastern states (Amyan \& Jawabreh, 2011; Jawabreh, 2017a).

Jordan is a preferred travel destination in the middle east (Alsarayreh et al., 2011). In Jordan, the industry makes a substantial contribution to the Jordanian economy. Kreishan (2011), noted that it accounted for $10.6 \%$ of the Jordanian GDP in 2009. Employment in the tourism cluster, including direct and indirect jobs, it was estimated at around 130,000 (11\% of the workforce). The Jordanian government has lately noticed a crucial role of tourism expansion in economic development and is eager to promote tourism internationally.

According to Hadadin et al. (2010), the crucial environmental challenge that Jordan faces today is the scarcity of water. While water resources in Jordan are insufficient and have swung around a stationary average, the country's population has continued to rise, further inflated by the influx of refugees. The water demands associated with tourism are not merely the demands of humans but also include demands from the need to maintain attractive landscapes and gardens. A high rate of natural population growth, combined with periodic massive influxes of refugees, has transformed a comfortable balance between population and water in the first half of this century into a chronic and worsening imbalance in the second half. Erdogan and Baris (2007), indicate that the hotel industry accounts for the consumption of substantial quantities of energy, burning of fossil fuels such as coal, oil and natural gas, water and non-durable products including food and beverages which cause a significant level of threat over environmental performance and contribute to global warming. 
A growing awareness has resulted in environmental preservation themes gaining support among many sectors in Jordan, including services, education and manufacturing. In particular, hotel operators especially in the resorts and historically significant areas like Aqaba, the dead sea and Petra in Jordan (Al-Weshah \& El-Khoury, 1999; Gradus, 2001; Scott et al., 2003; and Amr et al., 2004). The reason behind this is that many tourist activities are built on the environment, which constitutes the core value and the ground on which the activities take place. As reported by UNEP (2011), creating environmental awareness within an organisation has several benefits both within and out of the organisation. These benefits include reducing resources consumption, meeting compliances, increased customer loyalty and brand awareness when the environmental status is part of the marketing.

Jordan has adopted some legislative regulations, directives, environmental laws, and other measures, such as ISO having standard characteristics, which are to be applied and monitored by the government. This legislation seeks to address the challenges facing the preservation of the environment. The legislation has been in existence since the early 1950s (Al-Zu'bi, 2011; Jawabreh, 2017b; and Alananzeh et al., 2019).

The scarcity of resources and periodic shortages lead Jordan's government and its people to realise how important it is to implement various initiatives toward sustainable adoption practices. Some initiatives include, but are not limited to, supporting a range of policies and programs aimed at achieving greening initiatives such as the complete removal of subsidies for oil in 2008, the adoption of renewable energy law and fiscal intensive package in renewable energy and energy efficiency equipment in 2010, the establishment of the eco-city forum, the eco-financing seminar and the Zarqa River rehabilitation project (Shunnaq et al., 2008).

Phillips et al. (2003) ideas around Stakeholder Theory are used as a theoretical framework to explain the importance of environmental preservation extending to several parties such as the public, distributors, suppliers, customers both internal and external and macro-environmental factors such as the environment, which are directly affected by the performance of organisations and businesses. Combined with this recognition of stakeholders, concepts of strategic management of businesses in the form on environmental and operational management practices in the hotel industry were used to inform the conceptual framework.

Sloan et al. (2013) discuss the concept of sustainability and sustainability performance in hospitality businesses. They frame this as an operation concerned with the management of its resources in a manner that leads to the maximisation of the social, economic and environmental benefits. It, therefore, efficiently allows meeting the needs of the present generation, and at the same time, it also ensures the protection and enhancement of opportunities for future generations. In respect to hotels, sustainable or green hotels aim at reducing their impact on the environment and society. Robinson and Lynch (2007), and the American hotel and motel association describe green hotels as those that are environmentally sustainable properties and managers of such properties are highly eager to institute programs that are helpful in achieving savings of water and energy and allow for achieving the reduction of solid waste.

Berezan et.al (2013) when analysing the impact of sustainable practices adopted by hotels related the idea of sustainability to guest satisfaction and their intention toward return visitation. Repeat visitation is a fundamental strategy for profitability that businesses seek to cultivate. The authors observed that in addition to repeat visitation, 
properties and brands received added benefits of customer loyalty and reduced costs as well as an enhanced public image.

The review of the literature on environmental practices in Jordanian hotel and tourism sectors and the middle east more generally revealed the "gap" in the topic of this study. The identified gap led to the framing of the primary research question around business and operational practices of five-star hotels in Amman. Thus, the purpose of this study was to investigate sustainable environmental performance in hotels in Amman, Jordan. Data collection for the study included surveys and interviews with hotel managers and staff members of five functional departments such as maintenance and security (MS), kitchens $(\mathrm{K})$, food and beverage $(\mathrm{F} \& \mathrm{~B})$, housekeeping $(\mathrm{H})$ and purchasing $(\mathrm{P})$. The next section details the mixed method approach which was used to collect data regarding hotel manager's perspectives of environmental management and awareness levels of operational hotel staff regarding environmental practices in waste management, energy and water consumption and recycling efforts.

\subsection{Research Questions}

\subsubsection{Primary research question}

What business and operational practices are followed by five-star hotels in Amman, Jordan, to achieve sustainable environmental performance?

\subsubsection{Secondary research question}

What are the levels of awareness and attitudes of management and stakeholders toward environmental sustainability measures in five-star hotels in Amman, Jordan?

\section{RESEARCH METHODOLOGY}

\subsection{Research Subject, Information and Location}

The purpose of this study is to investigate sustainable environmental performance in hotels in Amman, Jordan. The primary objective of the research is to determine the impact of business and operational practices contributing to the sustainability of five-star hotels in Amman, Jordan.

For this research project on the sustainability of five-star hotels in Amman, semistructured interviews are the principal method of data collection. A convenience sample was employed for this study with all 13 five star rated hotel properties in Amman, Jordan approached to be part of the study. The researcher conducted 13 semistructured interviews with managers and employees from different hotel departments separately during August/2016. It is important to note that it was the month of Ramadan, very hot in Jordan and this might have introduced an unconscious bias in respondents particularly when answering questions around food wastage and water consumption. At this stage this is conjecture, and further research would need to be undertaken whether this hypothesis actually holds up to scrutiny and introduces a variable into the study. Each interview lasted between 20-30 minutes. Contingency plans are a necessary part of any research process, and in this instance, the researcher had to travel to Aqaba city to conduct some of the interviews with participants who were working in Amman five star hotels but lived in Aqaba to suit the convenience of the interviewees and reduce the attrition rate of the respondents.

\subsection{Data Collection Method and Analysis Techniques}

This paper highlights the findings of 13 semi-structured interviews with employees from 13 different five-star hotels in Amman and Aqaba. The in-depth semistructured interviews were employed to gather rich qualitative data. Employees interviewed included managers and supervisory staff from the five different operational 
departments maintenance and security (MS), food and beverage (F\&B), housekeeping $(\mathrm{HK})$, purchasing $(\mathrm{P})$, and kitchens $(\mathrm{K})$.

The empirical data collected was used to provide insights into the participant's demographic characteristics, as shown in Table 1.

Table 1

Interview Participant Characteristics

\begin{tabular}{|c|c|c|c|c|c|}
\hline \multicolumn{2}{|c|}{ Department } & Gender & Role & Education & Experience \\
\hline \multirow{2}{*}{$\begin{array}{c}\text { Maintenance and } \\
\text { security "MS" }\end{array}$} & MS1 & Male & Staff member & Diploma & 3 years \\
\hline & MS2 & Male & Supervisor & Bachelor & 2 years \\
\hline \multirow{3}{*}{$\begin{array}{l}\text { Food and } \\
\text { Beverage } \\
\text { "F\&B" }\end{array}$} & $\mathrm{F} \& \mathrm{~B} 1$ & Male & \multirow{3}{*}{$\begin{array}{c}\text { Supervisor } \\
\text { Bar and } \\
\text { restaurants staff } \\
\text { Waiter }\end{array}$} & Bachelor & 4 years \\
\hline & $\mathrm{F} \& \mathrm{~B} 2$ & Male & & Diploma & 5 years \\
\hline & $\mathrm{F} \& \mathrm{~B} 3$ & Male & & High school & 3 years \\
\hline \multirow{3}{*}{$\begin{array}{l}\text { Housekeeping } \\
\text { "HK" }\end{array}$} & HK1 & Male & Room attendant & High school & 2 years \\
\hline & $\mathrm{HK} 2$ & Male & $\begin{array}{l}\text { Housekeeping } \\
\text { Supervisor }\end{array}$ & DIP & 5 years \\
\hline & $\mathrm{HK} 3$ & Male & $\begin{array}{l}\text { Housekeeper } \\
\text { cleaner }\end{array}$ & HS & 2 years \\
\hline \multirow{2}{*}{ Purchasing "P" } & P1 & Male & $\begin{array}{l}\text { Purchasing } \\
\text { supervisor }\end{array}$ & $\mathrm{BACH}$ & 5 years \\
\hline & P2 & Female & $\begin{array}{c}\text { Purchasing } \\
\text { assistant }\end{array}$ & $\mathrm{HACH}$ & 4 years \\
\hline \multirow{3}{*}{ Kitchen "K" } & $\mathrm{K} 1$ & Male & Chef & $\overline{\mathrm{BACH}}$ & 3 years \\
\hline & $\mathrm{K} 2$ & Male & Head chef & $\mathrm{BACH}$ & 4 years \\
\hline & K3 & Male & $\begin{array}{c}\text { Cook and food } \\
\text { preparation }\end{array}$ & DIP & 2 years \\
\hline
\end{tabular}

As Table 1 shows, the diversity of the respondent's roles facilitated consideration and discussion of the different working conditions from diverse positions and with different hotels. Demographic data revealed a preponderance of male employees, especially in the kitchen area. This is concomitant of most kitchen brigades around the world. Interestingly participants referred to this gender inequity being part of the sustainability agenda, rationalising it saying that the nature of work precluded women from joining kitchens as chefs in Jordan. As one respondent said:

"Our responsibilities include butchering substantial amounts of meat as well as carrying large bags of rice and prepare huge platters. It is physically demanding (K2)".

The process of analysing qualitative data commenced with data collection and management. Transcripts were reviewed, including written statements by the researcher to organise and prepare the qualitative data. According to Patton (2005), transcribing is considered as part of managing and preparing data; it provides a shifting point between data collection and data analysis. After transcription, the data, short ideas, and concepts were summarised to make sense of the collected data. Data were coded, classified and categorised into the previously identified themes and subthemes derived from the pilot study, review of the literature and the survey instrument. The two main categories (themes) into which information was grouped were:

1) Business sustainable practices, and

2) Operational sustainable practices. 
Figure 1

A Framework of the Qualitative Data

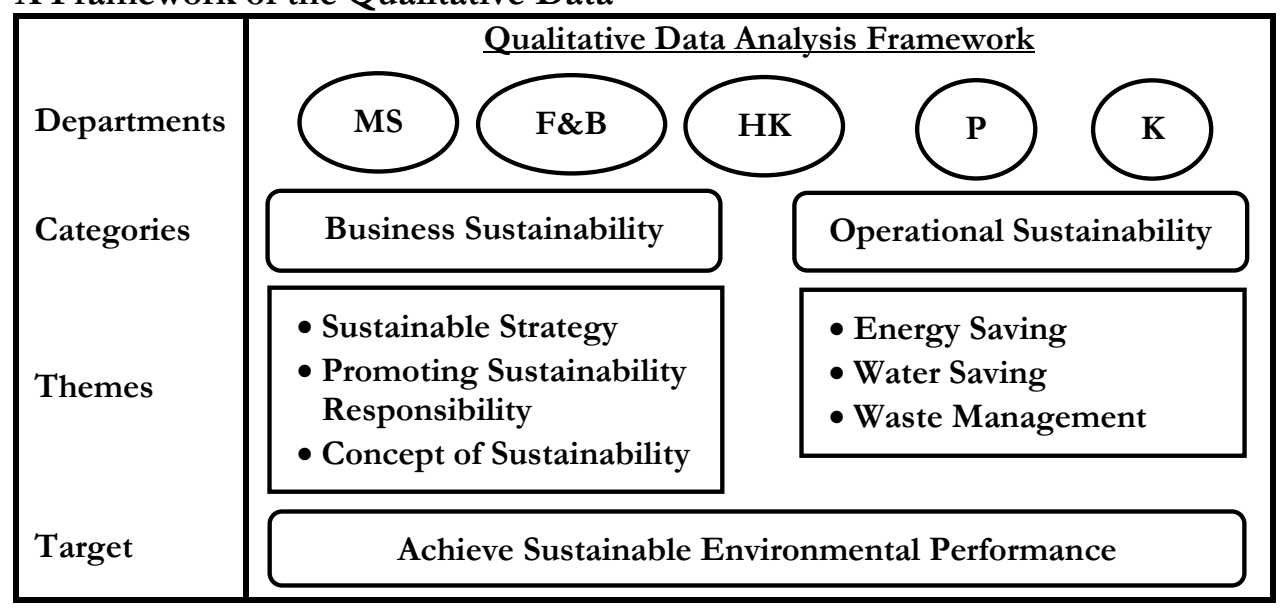

Each of these core themes also includes sub-themes that emerged from the responses of the study participants. The core and the sub-themes are the focus of the presentation of this chapter. The findings represented in this section emphasise the main themes and their sub-themes as illustrated in Figure 1.

Figure 1 demonstrates the framework of qualitative data collected in this study, through semi-structured interviews, with different managerial level staff from the five operational departments within the hotel. Business sustainability practices were further divided into sub-themes of sustainability strategies, promoting sustainability responsibility and the concept of sustainability. Operational sustainability included energy and water-saving and waste management.

\section{RESEARCH FINDINGS}

\subsection{Research Stages}

In this research on analysing sustainable and operational performance in five-star hotels in Amman, the researcher followed an inductive research approach for the collection of data. This study has integrated three stages to answer the primary and secondary questions. These stages are described below:

Stage one: the researcher conducted a comprehensive analysis of the literature which concentrated on previous studies and theories that were related to sustainability practices in hotels. The "so-what" question of the purpose of this research was also answered by the literature which revealed that sustainability is a significant concern to developing countries like Jordan if they are to maintain and grow their tourism and hospitality businesses.

Stage two: the data collection procedures in this study adopted a qualitative approach, with additional descriptive elements in the form of a survey to validate the research findings.

Stage three: data was collected in person by the researcher in Jordan. Descriptive statistics were applied to analyse demographic data. Thematic analysis approach was used to analyse qualitative data (semi-structured interviews). For the qualitative thematic analysis, the data was first transcribed from Arabic to English and then clustered based on themes identified through the literature prior. Once the data was collected it was transcribed, de-identified and collated, findings were discussed, conclusions elaborated and 
recommendations emerging for the industry, further studies and Jordanian tourism more generally were written up.

\subsection{Research Result and Discussion}

\subsubsection{Business sustainability}

In this section, the business sustainability theme is discussed through the lens of managerial staff in the five operational departments of the hotel properties used in the study. Sub-themes which were generated by interviewing respondents from the different departments included: sustainability strategy, promoting sustainability responsibility, and the concept of sustainability.

\section{1) Sustainability strategy}

There was collective agreement among all interviewees from the five operational departments that developing a sustainability strategy is essential to achieve sustainable environmental performance, by guiding the employees in the hotel's different operational sector to follow, adopt and implement sustainability practices in their operations and maintain high workplace safety.

All respondents agreed that adoption of sustainability strategies would give the hotels competitive advantages vs competitors who do not implement sustainability initiatives. The participants provided various points of view. Each participant explained the benefit of having a sustainable strategy in the hotel and following business practices that minimise the negative impact on the environment while positively impacting the hotel reputation and the brand image. Moreover, the participants declared that sustainable strategies have benefits of increasing profits while simultaneously decreasing operational costs. Also, the participants asserted that follow-through was important by monitoring employee's sustainable practices.

"Yes, I agree with that ... Hotels that have sustainability strategy

would attract more customers and, in the result, will increase its profit; nowadays, everyone is aware of the environment and the importance of being sustainable (MS2)".

The in-depth review of the literature, as shown earlier, illustrated the considerable amount of waste that the hospitality industry is responsible for producing. A significant part of hotel waste is food wastage. A set of specific and general questions were asked to Food and beverage interviewees to focus on specific conditions that exist in the $F \& B$ area. These issues aimed to examine the trends and features of $F \& B$ departments about environmental sustainability. Moreover, the interviewees reflected on the vision of their department regarding evaluating and applying sustainability strategies with one respondent saying:

"Hotels are considering sustainability strategy in the food and beverage department. Having accreditation from a well-recognised environmental organisation that award hotels for their achievement on sustainability practice can give the hotel better recognition by customers (F\&B1)".

In all the hotel departments, and particularly $F \& B$, achieving financial profitability play a vital role to improve the hotels' overall environmental and social performance. Two of the three participants (F\&B1 and 3) highlighted the issues around water and energy savings.

"A sustainability strategy in our department is compatible with the hotel strategy as we consider water saving, energy savings. That makes our 
department contribute to the whole sustainability strategy overall (F\&B3)".

Respondents expressed that each department should contribute to the holistic hotel strategy regarding sustainability practices by taking all aspects of saving measures in the primary three practices water, energy and waste management.

Moreover, the participants from housekeeping departments were asked about sustainability strategies and their perceptions of them. The respondents showed understanding and excellent knowledge of the water shortage problem in Jordan. HK 1 highlighted how this knowledge has been translated into sustainable actions regarding reducing water consumption.

"Sustainability can be achieved by respecting the environment which can save the cost of our operation, for example, encourage the customer to reuse the towels, and reduce water consumption ... you know we don't have water in Jordan ... we have to be wise when it's come to water (HK1)".

Interviewees were also aware of the positive social capital gained from enhancing local consumption regarding helping the community and building meaningful supplier relationships which made them less vulnerable to outside forces or unexpected events when imported goods become unavailable.

\section{2) Promoting sustainability responsibility}

Promoting sustainability responsibility is one of the sub-themes that were generated and identified through data analysis. Currently, the need for greener hotels is a growing demand with aware customers making purchasing decisions based on properties that demonstrate environmental responsibility. The hospitality industry has reacted to this trend and set policies to encourage 'greening' practices, ranging from savings in water and energy to having sustainable gardens on their premises. As one of the respondents from purchasing noted:

"Promoting sustainability is the hotel management's responsibility as mainly the hotel itself will get a lot of benefits. Many ways hotels can improve the sustainability practices may be through engaging customers and employees with hotels operation, for example, hotels can host bazaars for the local community where they promote their product, and in some cases, hotels make a purchase when the product is suitable for them (P1)". Jordan's economy is dependent on service industries, including tourism and transport activities. As mentioned in the literature review, Jordan is a non-oil-producing country with minimal natural resources and minerals. Moreover, Jordan faces challenges such as unemployment as well as inflation and a growing budget deficit. Therefore, the Jordanian government should pay serious attention to promoting and implement environmental sustainability in every aspect of life, not only the hospitality industry.

Respondents from the different departments agreed that hotel management and government at all levels should make more efforts to promote sustainability among the whole community, but the hotel industry needs to stand for sustainability practices as they are high users of non-renewable resources. Government plays a role through regulations and policies and promoting awareness about sustainability and sustainable practices amongst all stakeholders. However, there is often a disjunct between hoteliers and private businesses and government.

"Hotel management and government both responsible for making coordination to encourage sustainability practices among the community. 
But lack of communication between the hotel industry body and the government obvious (HK1)".

Governments need to enforce laws and regulation on business, including hotels to follow environmental sustainability practices. Additionally, the government should monitor hotels on a regular basis to make sure that hotels adhere to environmental regulations. The issue of sustainability needs to be addressed at different levels, in cooperation with academia, industry, policymakers, the public and other stakeholders. Thus, communication and regular contact and networking between assorted stakeholders is essential to achieve these sustainable practices.

When macro and microenvironments are considered, Government enacting legislation and regulatory frameworks that hotels must comply with definitely impact on the external conditions a company must follow. On micro-level hotel management, employees, suppliers and buyers taking responsibility and reducing their carbon footprint can also have a positive impact. In fact, hotels should seek not only to become carbon neutral but exceed minimum environmental benchmarks and set an example of conservation and sustainability, especially around scarce resources like energy and water in Jordan. The ability to actually contribute to positive action can be in the form of solar panels, water re-use and recycling efforts. Respondents claimed that promoting the sustainability message by hotel management can contribute to hotel success by marketing the hotel as environmentally friendly, which results in gaining competitive advantages.

Whether the issue is environmental protection, health and safety in either home or workplace, or consumption of goods and services, government regulations can have far-reaching effects and practical impact. Various environmental activities can also consider sustainable practices. Actions like recycling of materials, conservation of water and energy, protection of the different species, and preservation of historic resources often include sustainability goals in their intent and implementation. Respondents consistently referred to collaborative practice and a shared understanding of the sustainability agenda as being essential to effective action.

"I think the responsibility of promoting the sustainability responsibility among the hotels and their stakeholders can be through coordination between hotels and government... when all parties work together, results will be better (F\&B3)".

Moreover, participants interviewed from kitchen departments concurred that the responsibility to promote sustainability is everybody's responsibility, including government, industry, and community. Promoting sustainability responsibility in Jordanian hotels is affected by many barriers, such as the old-fashioned management styles and ignorance from the formal authority (government). Developing countries need to reassess their agenda related to sustainable initiatives; the current situation required more hard work to uphold the sustainable agenda, especially in the hotel industry. Moreover, hotels may play a primary role to host sustainable debates about sustainability to take part in promoting suitability in the country. This is particularly true of a country like Jordan, where the heritage and cultural tourism is of high economic value.

\section{3) The concept of sustainability}

The issue of sustainability is gaining significant attention within the hotel industry around the world. Sustainability concept, ('estidamah' in Arabic), is becoming increasingly popular in Jordan. Each industry has its measures and practices to achieve environmental sustainability performance. 
"Sustainability concept (estidamah) in the hotel industry is familiar, it means to me as respect the environment and saving natural resources, regarding sustainability, hotels trying to be more responsible for the environment and for the community where they are operating (MS1)".

Because of the increased awareness of the growing environmental degradation, people are becoming more mindful of the need for adopting and enforcing more effective measures of environmental protection. Environmental sustainability has become a vital priority and a challenge of the current time.

"Sustainability is about keeping the business environmental and green, with taking care of energy and water consumption ... in my opinion, it's about conserving resources and avoids using materials that harm the environment like plastic (HK1)".

Despite the scarcity of water and natural resources in Jordan as well as the fact that about $80 \%$ of the Kingdom's entire land is desert, Jordan plays a vital role to achieve sustainable environmental development. The government takes seriously environmental sustainability goals within the framework of national development policies; also, it takes necessary measures for conserving the environment and the optimal use of resources. However, as the respondents commented, more needs to be done in this respect to display these policies practically.

Sustainability and sustainable development are the primary aspects of Jordanian government planning and strategies in all aspects of economic and social sectors. However, implementing these policies requires effective coordination and integration with all parties. As the interviewees explained, there is an evident gap between the government, through its regulations and policies, and the private sectors, including hotels about environmental protection.

Having a recycling system that is appropriate for Jordan is very advantageous and would create jobs and business opportunities. Most of the waste in Jordan goes to landfill with a tiny portion being recycled. Creating jobs with a sense of considering the environment seems to be a very noble path. Respondents expressed a deep sense of what the recycling should be from different perspectives:

"... in my opinion, we follow kind of environmental practices when

it's come to water and electricity but, in Jordan for example, the waste including all types of waste is not managed... we just mixing the rubbish and all of it goes to the landfill (P1)".

The analysis of transcripts reveals that the interviewees have shown conscious awareness of the importance of environmental sustainability. Also, the interviewees showed an understanding of the challenges that Jordan faces is related to the scarcity of water and natural resources. Moreover, the respondents confirmed there is a responsibility on the government, hotel's management as well as other sectors, including the community to work together and to take more thoughtful steps toward sustainability and environment conservation.

Sustainability concept in the Jordanian hotel industry is gaining momentum in the last few years. A respondent from the F\&B department indicated that sustainability is seen as a positive movement toward achieving not only competitive advantages but also towards protecting the environment. Hotels are working toward following environmentally friendly practices in daily operations to save money, gain more profit and attract more customers. 
“...as a concept, it means to be running the business in a responsible way ... saving resources (water and energy), recycling and manage the waste (F\&B1)".

Sustainability concept is gaining more weight in the last few years. The concept of sustainability from purchasing department interviewees varied from the general aspect of the concept to more specific green procurement. Purchasing department participants showed a rational understanding of sustainability, meaning which includes, as described by Sloan et al. (2013) is about meeting the present generation needs without compromising future generation resources.

"I believe sustainability is about to improve the quality of our life and be aware of the environment and save it for our next generation (P1)".

The concept of environmental sustainability, specifically within the purchasing department, refers to the purchasing of goods and services that reduce the negative impact on the environment. It is also about procuring goods locally as far as practically possible to reduce the pollution and costs associated with 'miles travelled between production and consumption'. When considering food products that are out of season or need specific heating or cooling temperatures, costs increase in proper storage facilities as well as transportation costs. The purchasing department has a significant impact on the hotel's overall financial and environmental performance.

"Sure, we consider the environment in every purchasing deal. I

mean packaging, operation, or when we buy any product (P1)".

Respondents from the kitchen department defined the concept of sustainability differently emphasising the need to be considering community views and following specific policies for measuring and evaluating their current practices.

"Hotels in Jordan demonstrate the concept of sustainability in all activities... the idea of sustainability extends to include a way of thinking to be responsible toward the environment and community (K1)".

The analysis of the transcript of the interview has shown that participant from all departments had a good understanding of the meaning of sustainability, however, environmental sustainability practices needed to be operationalised and integrated into all aspects of the operation as an integrated whole.

\subsubsection{Operational sustainability}

The following section will discuss the operational sustainability practices followed in five star hotels in Amman, Jordan, through five operational departments. The operational sustainability subthemes are energy saving, water saving and waste management.

\section{1) Energy saving}

In regard to energy saving, respondents mentioned various practices that help save energy and as a result, save cost. Profit and saving cost are the driving factors that encourage hotels toward responsible and sustainable operations. Financial saving can be achieved by investing in better environmental, operational procedures and emerging environmental technologies.

"Our hotels make right steps with saving energy by replacing old

lights with new power savings bulbs; this action saved much money on the electric bill, not sure how much saving, but am sure it saves a lot of dinars (MS1)".

Power saving bulbs are widely used in Jordan. Householders are making the steps of changing their non-saving lights with energy-saving bulbs. Business firms are 
also exploring any opportunity to save on their electric bills. Energy conservation in Jordanian hotels is addressed as an essential element of sustainability practices. However, what the respondents stated refers to simple methods, for example, changing the old bulbs into energy-savaging bulbs. Some hotels are considering other aspects of saving energy, such as using solar power for heating the swimming pools instead of electricity. Solar panels are also an option given the abundant sunlight in Jordan.

Energy savings in Jordanian hotels is considered as a significant challenge as the government is putting the electricity price up as a result of the global rise in petrol prices. Respondents expressed their concerns as there is no effective coordination between the stakeholders to make an outstanding improvement regarding energy saving. Jordan has abundant supplies of new and renewable energy sources, such as oil shale and solar power.

Food and beverage department respondents rated the energy savings as the priority for their hotels by using energy-saving appliances in their department. There are many ways to save energy in F\&B departments such as installing or replacing faucet aerators, replacing older pre-rinse nozzles, maintaining walk-in refrigeration unit doors and installing demand-responsive ventilation conversions.

"Energy saving in F\&B department is critical as the unit using much equipment that environmental and save energy consumption. Hotel management replaces the old electrical equipment with new energy conservation to conserve energy... for sure the new stuff with saving energy label consuming less energy (F\&B1)".

According to HK respondents, hotel management provides the staff with simple training and instructions on how to save energy through direct supervision, or what is called (in-job training). To entrench energy-saving practices among staff and employee, hotel managers have to consider the implementation of energy-efficient technologies and more importantly enhancing energy behaviour among employees.

"HK department deals with all aspects of cleaning activities in the hotels... all machines are required power. I believe energy saving can be achieved by using energy-efficient new technology in addition to engaged employees and strict supervision (HK3)".

All interviewees from housekeeping departments described energy-saving practices followed in their hotels. The energy-saving practices and appliances used in five-star hotels in Amman regarding energy conservation include having systems to control and monitor heating, ventilation and air conditioning, and using low-energy lighting. Also, it found that adopting energy efficiency measures are not only going to prove financial benefits but are also likely to benefit the reputation of the hotel.

As discussed previously, initiatives toward energy conservation consistently exist in Jordanian five-star hotels. These efforts include changing the old light bulbs with energy-efficient bulbs, adopting energy star certified appliances such as ovens, stoves and refrigerators. Just as any business, hotels depend heavily on the performance of the employees to meet the demands of customers and guests; the energy efficiency plan needs the support of the entire team to achieve the desired outcomes and attain energy efficiency benefits.

\section{2) Water saving}

Water scarcity in Jordan has become an even greater problem in Jordan with the influx of around 1 million refugees from neighbouring countries, especially from Syria in the last few years. Jordan is struggling to meet its own resident's water needs, but since the refugee influx, the issue of water shortage has become even more challenging. 
Hotels consume a significant amount of water every day in their operational activities which include cleaning, laundry, bathrooms, swimming pools, irrigation, recreation, services, food preparation and other aspects. The high cost of water and its limited availability all result in hotels are an impetus for water preservation.

"Hotels using water-saving devices to reduce the water consumption in most of our operations, using the dual flush in toilets and use the saving shower head, I believe that saving water resources in Jordan should be everyone concerned as the country having real challenges on water supply (MS1)".

There are many water-saving devices in the hotel industry; the most commonly used include the dual flush system and the showerhead. Rainwater catchment and harvesting is another technique as sustainable and cheap practices of water-saving, but unfortunately, most of the hotels do not utilise this option in their consideration of sustainable practices.

Respondents expressed awareness of the water supply problems in Jordan. Moreover, the participants illustrated the hotel's initiatives toward being more efficient and water-wise by encouraging guests and staff to be conservative when using water in the hotel. Examples of such savings include the 'reuse' towel programme saving in laundry water use as well as hanging posters in public and private spaces reminding customers and employees to be mindful of their usage of amenities. Refillable amenities like soap, shampoo etc. are also becoming the norm instead of single use disposable plastic containers.

In summary, Jordan has one of the lowest levels of water resource availability per capita in the world. Water scarcity will become a more significant problem over the next two decades as the population doubles, and climate change potentially makes rainfall more uncertain and variable. Scarcity of water supply has been highlighted by respondents as a significant problem, especially in the hotel industry. Respondents expressed their opinions and uncertainty about water shortage in Jordan and how that is affecting the hotel industry.

"Jordan is struggling to supply water for the household and industries. I am very concerned about how Jordan will meet the high demand for water in all sectors... our hotels, we try to be very wise on consuming the water because first to save the operation cost and save the resources. We apply water-saving policy such as using water-saving in toilets flush, and water savings showerheads device (HK1)".

Using water efficiency machines such as dishwasher and laundry can reduce water consumption and consequently save costs. Also, saving water can contribute to achieving the sustainability vision of the hotel. Respondents claimed that the staff should operate machines like washers for hard surfaces and sprinklers economically to save the cost of the operations. This is achieved through simple measures like not running the dish and laundry machines unless they are full and running them on economic cycles and using cold water when possible. Moreover, as the participants remarked on the practices that were followed in the hotels regarding water consumption, they highlighted the lack of policies and procedures which contributed to a lack of awareness of water waste in Jordan and particularly in the hotel industry.

As the respondents highlighted, an essential aspect of implementing water policy is to communicate with and educate the staff as well as the community. Moreover, as the respondents noted, the government plays a vital role regarding saving water consumption not only by supplying water but, equally important, by enhancing the 
community attitudes and behaviours when it comes to water consumption. Where water is in short supply, being aware of competing demands for water and availability issues for a local community is vital. Hotels should cooperate with local communities when it comes to water consumption, rather than just taking supplies from them. This would further relationships between locals and the hotels as well as reduce exploitation of resources and perceptions that tourists were being favoured over locals.

Hotels can play a significant role in educating guests about water issues in Jordan and the importance of following water conservation practices. Simply, this can be done by communicating the hotel water policy and making it noticeable for customers through employees' practices. Jordanian hotels are responsible for delivering to guests the importance of freshwater resources within the area and provide opportunities to allow guests to use water wisely. Interviewees from the purchasing department highlighted that they are promoting the purchase of water-conserving products.

"Water scarcity in Jordan is major concerns for everyone; the hotel

is not the exception, our hotel implemented a water-saving technique to save the water wherever possible for example the Dual-flush system in toilets and water-saving showerhead applied to minimise water consumption (P1)".

Hotel management are required to create a water conservation plan which must be communicated clearly to all employees in every department. Each operational department can play a significant role, through their responsibilities, to achieve a water conservation plan. Efforts should be integrated and coordinated with all departments, management, customers and community.

With regards to water, all interviewees from the five operational departments agreed that the Kingdom of Jordan is facing huge, challenging water scarcity. The analysis showed the extent of awareness among all interviewees of the importance of following water efficiency strategy. Conserving water will not only save money, but it will also provide a significant marketing advantage in such a competitive industry. Protecting the country's limited water resources is a significant part of maintaining that competitive advantage.

\section{3) Waste management}

There is a lack of distinct policy and strategy dealing with waste in Jordan. Jordan still has not developed procedures to manage waste through reduction, reuse and recycling. All respondents agreed that waste management in Jordan is not well managed. Moreover, the respondents asserted that the government should enforce regulations and policies on all manufacturing and service sectors to address the problem of waste management. All respondents noted that waste management in Jordan generally, and in the hotel's industry specifically, needs a lot of work and serious initiatives. They especially noted that despite the efforts in the hotel to recycle, this was not followed through and everything ended up in a landfill.

"Our hotel is adopting a recycling program, and we separate the rubbish per its types such as carton and plastic. But at the end of the way, most of the rubbish going to the landfill (MS1)".

Jordan is still in the infancy stages of having recycling programs and enforcing them. When probed, the respondents mentioned that there are some private companies collecting commercial and industrial waste and direct transport of waste after collection to transfer stations and landfills. However, Jordan follows unsophisticated practices regarding solid waste management which include limited separation of useful materials in landfills and partial recycling of certain kinds of waste. 
Waste management sector is one of the major challenging issues in Jordan. A respondent from the $\mathrm{F} \& \mathrm{~B}$ department claimed that waste management needs more attention from the government and hotel industry firms. The respondents expressed concerns and suggestions on how to address the issue. Relating to waste in the hotel industry the interviewees admitted that they have a waste policy in each hotel, but they expressed their concern about the policy and the practices in the hotels themselves and the waste treatment outside the hotels. Food and beverage departments are responsible for creating massive amounts of waste while preparing, cooking and serving food. Waste produced by this particular department includes solid waste, water waste and food waste.

"The hotel implementing waste policy in such as separating waste

in the public area in the hotel one for recycling and the other for rubbish

... water waste just goes in the sewage (F\&B1)".

As mentioned earlier, hotels are responsible for generating a significant proportion of waste. Waste in hotels has many components, including paper, food, various metals, plastics, aluminium, and glass. Analysing of interviews transcripts show that interviewees from housekeeping departments are aware of the issue of waste management in Jordan.

"Waste management in Jordan still not reasonable industry when it

comes to commercial aspects, for this reason (HK1)".

Waste management in Jordan has been improved for the last 15 years since the mid-1990s, with the improvement of the legal framework and institutional capacity to be the primary drivers of the sector's development. Despite the lack of clear and welldefined policy and strategy, the hotels follow simple practices to manage waste, these practices include recycling and reusing. Hotels can reduce the amount of waste produced by applying and following waste management practices that are demonstrated around the concepts of reducing, reuse and recycle. Moreover, employee involvement is necessary for the achievement of any environmental program. Employee engagement through educational opportunities, adequate supervision, newsletters, and other means, encourages staff to become involved in a hotel's environmental program.

Interviewees from purchasing departments similarly confirmed that their hotels adopted and monitored the use of sustainable standards in procurements. The purchasing strategy involved reviewing the products and services that the hotel purchase regularly and selecting ones with reduced environmental impact. These standards are applied to all the essential items in the hotels, including equipment, energy, water, paper, cleaning, and furniture. Regarding waste management, respondents asserted that the issue of waste management in Jordan generally and in the hotel's, industry particularly is underestimated and underdeveloped.

Sustainable procurement policy stimulates the market regarding a more innovative and sustainable approach to procurement. Sustainable procurements also involve examining the entire product life cycle from start to finish as well as exploring the possibility of fair-trade, certified organic and local products.

Regarding waste management practices within the purchasing department, the respondents noted that selecting environmentally friendly and socially responsible products is part of the hotel procurement strategy. The hotels are working toward reducing the purchasing and the use of environmentally harmful substances such as toxic chemicals. Furthermore, waste and mainly food waste have become a big issue in all hospitality sectors, including hotels. There are many aspects in which food waste 
impacts the environment. Understanding the effects is the first step in helping to make a difference.

"We do have a waste management policy in the hotel; we separate the recycling material from the rubbish ... we produce a lot that can be used as fertilisers but unfortunately goes to landfill end of the day (K1)".

At this stage, hotels in Jordan do not have exact figures available for the cost and volumes of food waste produced in this industry. According to the interviewees, a considerable number of leftovers and the surplus food is thrown away in the rubbish daily. Also, allowing all the food waste to be sent to landfills is harmful to the environment, because the waste produces methane upon decomposition, which contributes to global warming. The respondent asserted that regarding leftover food, they are donating food items to non-profit organisations.

\section{CONCLUSION, SUGGESTION AND LIMITATION}

\subsection{Conclusion}

The study results revealed several sustainability practices that existed already. However, issues of water scarcity and savings in Jordanian hotels emerged as a pressing issue. The study demonstrated there is a critical need to adopt a clear sustainability strategy that involves and includes all stakeholders to create a significant contribution and to improve environmental sustainability performance within the hotel's industry in Jordan. Moreover, the study revealed preliminary and initial initiatives toward waste management which include reusing and recycling while implemented were less than adequate as despite sorting waste at the property, most of it was mixed and ended up in landfill once it left the hotel. Unsurprisingly gender inequity within the Jordanian hotel industry was highlighted and sustainability efforts and policies need to change to introduce more diversity not only in gender but also culture and ability.

Regarding waste management practices within the purchasing department, the respondents noted that selecting environmentally friendly and socially responsible products is part of the hotel procurement strategy. Moreover, hotels are working toward reducing the purchasing and the use of environmentally harmful substances such as toxic chemicals. Furthermore, waste and mainly food waste have become a big issue in all hospitality sectors, including hotels. There are many aspects in which food waste impacts the environment. Understanding the effects is the first step in helping to make a difference.

Hotel management required creating a water conservation plan which must be communicated clearly to all employees from all the business departments. Each operational department can play a significant role, through their responsibilities, to achieve a water conservation plan. Efforts should be integrated and coordinated with all departments, management, customers and community.

Energy savings in Jordanian hotels is considered as a significant challenge as the government is putting the electricity price up as a result of the global rise in petrol prices. Respondents expressed their concerns as there is no effective coordination between the stakeholders to make an outstanding improvement regarding energy saving. Jordan has abundant supplies of new and renewable energy sources, such as oil shale and solar power.

The analysis of the transcripts of the interviews has shown that participant from all hotel departments had a good understanding of the meaning of sustainability concepts in Jordanian hotel operation context. In all the hotel departments, and particularly the food and beverage department, there is a challenge to achieve financial 
profits while improving environmental performance. Adoption of environmental practices is fundamental to meet this challenge. Moreover, the food and beverage department can play a vital role to improve the hotels' overall environmental and social performance.

This study contributes to knowledge in this field by identifying the actual sustainable performance of five-star hotels in Amman, and how sustainable practices can contribute positively towards allowing hotels to achieve better performance towards the environment. Because of greater concerns of threats to the environment by the hotel industry, the findings of this research are useful in allowing the hotels to deal better with the environmental issues that are a result of the nature of their business. The study findings also provide necessary recommendations to the hotels in Amman in achieving sustainable performance from their regular business practices and increasing overall performance.

\subsection{Suggestion and Limitation}

No research is without limitations. The difficulty of generalising the findings of the current study to the Jordanian hotel industry is one of its limitations due to its small sample size and targeted respondents of five-star properties in metropolitan Amman. Another 'introduced variable' was the timing of the data collection which coincided with the month of Ramadan, which potentially impacts the participant's availability due to the change of working hours and lifestyle routine. The researcher dealt with this issue by being more flexible in collecting data upon the participant's availability and travelling from Amman to Aqaba to meet some of the participants. This study highlighted suggestions for future researchers to consider collecting data timing to facilitate the research process and receiving data. Additionally, limitations of time, money and scope are always attendant in research which is conducted in the field. Despite having contingency plans in place, inevitably decisions have to be made depending on circumstances around observational research.

\section{REFERENCES}

Alananzeh, O., Al-Badarneh, M., Al-Mkhadmeh, A., \& Jawabreh, A. (2019, November). Factors influencing MICE tourism stakeholders' decision making: The case of Aqaba in Jordan. Journal of Convention \& Event Tourism, 20(1), 24-43. Https://doi.org/10.1080/15470148.2018.1526152.

Al-Hussein, M., Jawabreh, O., Alananzeh, O., \& Ali, M. (2015). The impact of understanding the behavior of workers on the success of management (a case study of five star hotels in Aqaba). Journal of Management Research, 7(3), 51-70. https://doi.org/10.5296/jmr.v7i3.7115.

Al-Shawagfih, K. F. A., Alananzeh, O. A., \& Jawabreh, O. A. A. (2015, October). The foundations of selecting cultural tourism product in Jordan. European Scientific Journal, $11(29)$, 198-207.

Alsarayreh, M. N., Jawabreh, O. A., ALkharabsheh, K. S., \& Aldahamsheh, M. M. (2011). Tourism promotion through the internet (websites): Jordan as a case study. Asian Social Science, 7(6), 125-135.

Al-Weshah, R. A., \& El-Khoury, F. (1999, May). Flood analysis and mitigation for Petra area in Jordan. Journal of Water Resources Planning \& Management, 125(3), 170-177.

Al-Zu'bi, A. (2011). Evaluation of the Jordanian environmental legislations. World Applied Sciences Journal, 14(10), 1438-1444. 
Amyan, M., \& Jawabreh, O. (2011, January). Mutual impact between tourism and the host community (a case study of Wadi Rum). European Journal of Social Sciences, 19(1), 30-40.

Amr, Z. S., Hamidan, N., \& Quatrameez, M. (2004). Nature conservation in Jordan. In W. Waitzbauer, R. Albert, B. Petutschnic, \& G. Aubrecht (Eds.), Reise durch die natur Jordaniens (1 ${ }^{\text {st }}$ ed., pp. 467-477). Land Oberösterreich, Oberösterreichisches Landesmuseum, Biologiezentrum. Retrieved from http://www.zobodat.at/ web4beta/pdf/DENISIA_0014_0467-0477.pdf.

Ballantyne, M., \& Pickering, C. M. (2013, December). Tourism and recreation: A common threat to IUCN red-listed vascular plants in Europe. Biodiversity \& Conservation, 22(13-14), 3027-3044.

Berezan, O., Raab, C., Yoo, M. \& Love, C. (2013, September). Sustainable hotel practices and nationality: The impact on guest satisfaction and guest intention to return. International Journal of Hospitality Management, 34(1), 227-233.

Erdogan, N., \& Baris, E. (2007, April). Environmental protection programs and conservation practices of hotels in Ankara, Turkey. Tourism Management, 28(2), 604-614.

Gradus, Y. (2001, May). Is Eilat-Aqaba a bi-national city? Can economic opportunities overcome the barriers of politics and psychology? GeoJournal, 54(1), 85-99.

Hadadin, N. A., Qaqish, M., Akawwi, E. J., \& Bdour, A. (2010, January). Water shortage in Jordan - Sustainable solutions. Desalination, 250(1), 197-202.

Han, H., Hsu, L.-T. J., \& Sheu, C. (2010, June). Application of the theory of planned behavior to green hotel choice: Testing the effect of environmental friendly activities. Tourism Management, 31(3), 325-334.

Jawabreh, O. A. A. (2017a, October). Distinction of Jordan as a destination for religious tourism. Journal of Environmental Management \& Tourism, 8(6), 1171-1182. Https://dx.doi.org/10.14505/jemt.v8.6(22).03.

Jawabreh, O. A. A. (2017b). An exploratory study of the motives of Jordanian out bound tourism and its impact on the development of tourism in Jordan. International Journal of Applied Business \& Economic Research, 15(26), 443-467.

Kang, K. H., Stein, L., Heo, C. Y., \& Lee, S. (2012, June). Consumers' willingness to pay for green initiatives of the hotel industry. International Journal of Hospitality Management, 31(2), 564-572.

Kirk, D. (1995). Environmental management in hotels. International Journal of Contemporary Hospitality Management, 7(6), 3-8. Https://doi.org/ 10.1108/09596119510095325.

Kreishan, F. M. (2011). Time-series evidence for tourism-led growth hypothesis: A case study of Jordan. International Management Review, 7(1), 89-93.

Manaktola, K., \& Jauhari, V. (2007, July). Exploring consumer attitude and behaviour towards green practices in the lodging industry in India. International Journal of Contemporary Hospitality Management, 19(5), 364-377.

Patton, M. Q. (2005). Qualitative research. In Brian S. Everitt \& David Howell (Eds.), Encyclopedia of statistics in behavioral science (3, pp. 1633-1636). Chichester: John Wiley \& Sons, Ltd

Phillips, R., Freeman, R. E., \& Wicks, A. C. (2003, October). What stakeholder theory is not. Business Ethics Quarterly, 13(4), 479-502.

Robinson, M., \& Lynch, P. A. (2007, December). The power of hospitality: A sociolinguistic analysis. In Conrad Lashley, Paul Lynch, \& Alison Morrison (Eds.), Hospitality: A social lens (pp. 141-154). London, UK: Elsevier Science. 
Scott, C. A., El-Naser, H., Hagan, R. E., \& Hijazi, A. (2003). Facing water scarcity in Jordan: Reuse, demand reduction, energy, and transboundary approaches to assure future water supplies. Water International, 28(2), 209-216.

Seetharaman, A., Patwa, N., Jadhav, V., \& Saravanan, A. S. (2016, October). Accounting and financial systems and tools for effective leadership and management. Journal of Accounting-Business \& Management, 23(2), 45-60.

Shunnaq, M., Schwab, W. A., \& Reid, M. F. (2008). Community development using a sustainable tourism strategy: A case study of the Jordan river valley tourist way. International Journal of Tourism Research, 1(10), 1-14.

Sloan, P., Legrand, W., \& Chen, J. S. (2013). Sustainability in the hospitality industry: Principles of sustainable operations ( $2^{\text {nd }}$ ed). London \& New York: Routledge, Taylor \& Francis Group.

UNEP (The United Nations Environment Programme). (2011, August). Towards a green economy in Jordan. Ministry of environment (pp. 1-33). Retrieved Agustus 12, 2016, from http://www.greengrowthknowledge.org/sites/default/files/downloads/ resource/Green_Economy_Jordan_UNEP.pdf.

Wyngaard, A. T., \& De Lange, R. (2013, September). The effectiveness of implementing eco initiatives to recycle water and food waste in selected Cape Town hotels. International Journal of Hospitality Management, 34(1), 309-316. 